\title{
AGRARIËR VRAAGT NIET SNEL OM HULP
}

\section{— De doorsnee agrariër zoekt niet snel psychosociale hulp. Toch staat de boer van vandaag sterk onder druk en ligt een burn-out op de loer. Hulpverleners hebben te weinig inzicht in wat deze specifieke doelgroep nodig heeft. Daarom heeft Agrozorgwijzer samen met andere betrokken partijen een Agro-Zorgnetwerkkaart gemaakt.}

De kaart dient als een brug tussen de hulpverlening en de, soms zorgmijdende, agrariër die hulp nodig heeft. De speciale Agro-Zorgnetwerkkaart is niet meer dan een praktisch diagram, dat zowel agrariërs als hulpverleners laat zien wie er allemaal in het netwerk van de boer zitten en welke hulp beschikbaar is. Want wat weet je als hulpverlener eigenlijk van zo'n specifieke beroepsgroep als agrariërs?

'Het is een groep apart en de zorg is niet goed op hen aangesloten', zegt Fleur Bartels. Zij werkt aan het project Agrozorgwijzer namens LTONoord. Deze vereniging behartigt de belangen van boeren en tuinders boven de Maas en telt zo'n 25.000 leden. 'Een boer woont op zijn werkplek en werkt vaak alleen. Als er dan iets misgaat, is het lastig dat werk en privé zo verweven zijn. En als je dan naar de huisarts of maatschappelijk werk stapt met je zorgen, dan hoor je: $\mathrm{u}$ moet het rustiger aan doen, ga er een paar weken tussenuit. Een agrariër denkt dan: die begrijpt het echt niet. Hij of zij kan het bedrijf niet zomaar een tijd sluiten; de koeien moeten bijvoorbeeld toch echt gevoerd en gemolken worden.'

De agrarische beroepsgroep staat onder grote maatschappelijke en politieke druk en 'overwerkt' en 'burn-out' behoren tot veelgehoorde klachten. 'Er spelen diverse factoren', zegt Bartels. 'Sommige melkveebedrijven zijn groter geworden, maar kunnen niemand aannemen en de boer blijft het werk allemaal zelf doen. Denk aan melken en landwerk, zoals maaien en mesten. Dat komt soms door financiële redenen, soms omdat de boer het altijd zelf gedaan heeft en het liever in eigen hand houdt.'

\section{'Deze beroepsgroep staat onder grote druk'}

\section{$\underline{\text { Onder druk }}$}

Een pak verantwoordelijkheden, waarbij ook externe partijen de boer onder druk zetten. 'Je hebt niet alleen met de overheid te maken, denk aan de stikstofdiscussie en de ammoniakuitstoot. Maar ook de afnemer van het product, zoals de zuivelonderneming of uienhandelaar heeft kwaliteits- en imago-eisen. Je krijgt van alles opgelegd, er ligt veel op je bord. Aan de ene kant houden agrariërs van hun vak, het buitenzijn, de vrijheid. Aan de andere kant voelen velen zich onmachtig, soms radeloos. Een nieuwe stikstofmaatregel of een persoonlijk probleem, zoals een ziek kind, kan dan de druppel zijn die de emmer doet overlopen.'

Een boer kan worden gezien als een zorgmijder. Hij of zij zoekt niet snel hulp en als de agrariër al bij de huisarts op spreekuur komt, weet die niet altijd wat er achter de klachten schuilt. 'Huisartsen geven aan: een boer komt vanwege de pijn in zijn knie. Maar er zit vaak meer achter', zegt Bartels.

Er zijn speciale hulpinitiatieven voor agrariër zoals agro-coaches. 'Die worden meestal aangesproken door mensen uit het netwerk om de boer heen. De boer werkt alleen, maar er komen allerlei mensen op zijn erf zoals de dierenarts, loonwerker, buurman of boekhouder. Zij zijn vaak 


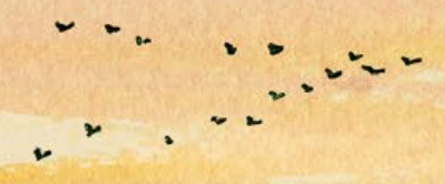

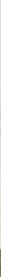

ant

mon

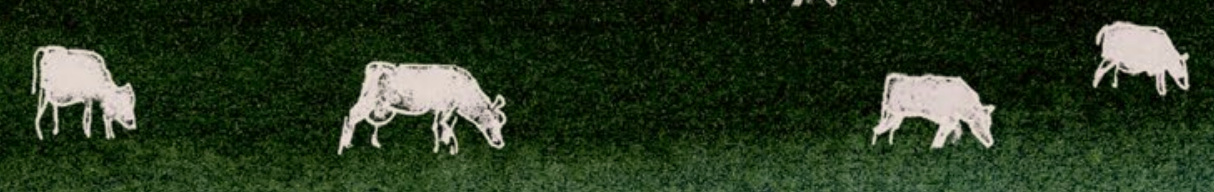


degenen die binnen het agrozorgnetwerk een melding doen, in totaal gaat het om een paar honderd meldingen per jaar. Bijvoorbeeld een dierenarts die signaleert dat de boer zijn dieren niet goed meer verzorgt, omdat het niet goed met hem gaat.'

\section{$\underline{\text { Suïcides }}$}

Er moet wat gebeuren om de boer de juiste hulp te bieden, aldus Bartels. 'We hebben geen concrete cijfers om het probleem in kaart te brengen, maar we zien dat het probleem groter wordt. In andere landen stijgt het aantal suïcides onder agrariërs. In Nederland meten we dit niet speciaal onder beroepsgroepen, maar we denken dat deze trend ook voor Nederland geldt.'

Met de ontwikkeling van de Agro-Zorgnetwerkkaart willen organisaties uit de agrarische sector en de reguliere hulpverlening, met ondersteuning van het ministerie van Landbouw Natuur en Voedselkwaliteit (LNV), het netwerk rondom de agrariër beter vindbaar maken. Het idee is simpel: de Agro-Zorgnetwerkkaart is een pdf met daarop een rond wiel, waarin het netwerk van de agrariër wordt omschreven. Van alle soorten hulpverlening zoals de reguliere hulpverlening (bijvoorbeeld huisarts en GGD) en agro-sociale hulp (denk aan agri-mediation) tot agrarische contacten (zoals veehandelaar en agrarisch bedrijfsadviseur). Daardoor zien de boer, zijn gezin en erfbetreders in één oogopslag waar zij terecht kunnen met een hulpvraag, en hulpverleners snappen beter hoe het netwerk van de boer eruit ziet. Bartels: 'De kaart is door alle betrokken partijen, zoals GGD en huisarts, verspreid onder hun professionele contacten. Wij hebben de Agro-Zorgnetwerkkaart via een nieuwsbrief naar onze leden gestuurd en verspreid binnen het agrarische netwerk. We hopen komend jaar de kaart online en interactief te maken.'

\section{Effect}

De Agro-Zorgnetwerkkaart is begin dit jaar gelanceerd, maar het effect is nog niet te meten, aldus Bartels. 'We krijgen wel positieve reacties vanuit de hulpverlening. Zij zijn verbaasd dat er zoveel partijen om agrariërs heen zitten. Dat is in elk geval al meer bewustwording. Door alle aandacht voor het coronavirus kunnen we dit nu even niet verder uitbouwen.'

De pandemie zorgt ongetwijfeld ook voor meer stress bij boeren? 'Ja, vooral onder bloementelers. Daar vielen de eerste klappen, alles lag meteen helemaal stil, omdat de bloemen niet meer worden geëxporteerd en ze ook zonder buitenlandse seizoenwerkers zitten. Maar ook andere agrariërs voelen het enorm. De een kan het hebben, bij de ander staat het elastiekje al strak.' Wat kunnen hulpverleners leren van het zorgisolement van een specifieke beroepsgroep? Bartels: 'Verdiep je in je cliënt. Je moet begrip voor zijn bestaan krijgen. Alleen als je hem begrijpt, kan je de juiste hulp bieden.' <

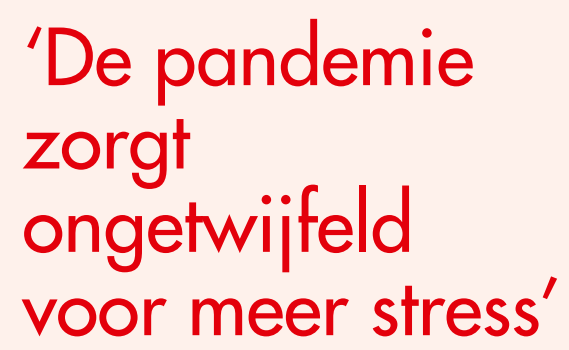

\section{AGRI-MEDIATION}

De broers Bram* (51) en Joop (48) hebben een melkveehouderij in Noord-Holland. Ze hebben het bedriif overgenomen van hun ouders en werken al tientallen jaren goed samen. Maar dan kriigt Bram een motorongeluk en moet hij een jaar revalideren. Het loopt mis in het bedrijf. Joop is minder gestructureerd en slordiger dan Bram en heeft het nu veel drukker, ondanks het feit dat zijn oudere broer probeert zoveel mogelijk mee te helpen. Ze krijgen hoogoplopende ruzie. Bram moet regelmatig naar de huisarts vanwege lichamelijke klachten, zijn herstel vordert niet goed. Er is meer aan de hand dan lichamelijke problemen, maar de huisarts pikt de signalen niet op. De dierenarts merkt echter dat het niet goed gaat met het vee. De melkkwaliteit gaat achtervit en er lopen koeien kreupel. Ze zijn niet verwaarloosd, maar krijgen duidelijk minder zorg. De dierenarts trekt aan de bel binnen het netwerk: het Vertrouwensloket Welzijn Landbouwhuisdieren. Er wordt bemiddeld middels agrimediation. De broers gaan praten met elkaar en er wordt voorlopig extra mankracht aangenomen. Een typisch voorbeeld van agrarische problemen en een agrarische oplossing.

Wat kan de Agro-Zorgnetwerkkaart hier doen? In dit geval de huisarts alerter maken en laten zien waar deze in het netwerk de juiste hulp kan vinden.

*De namen en locatie zijn gefingeerd om anonimiteit te waarborgen. 